\title{
Effect of Pressure and Fat Content on Particle Sizes in Microfluidized Milk*
}

\author{
D. W. Olson, ${ }^{1}{ }^{1}$ C. H. White, ${ }^{1}$ and R. L. Richter ${ }^{2}$ \\ ${ }^{1}$ Department of Food Science and Technology \\ Box 9805, Mississippi State University, Mississippi State 39762 \\ ${ }^{2}$ Department of Animal Science \\ Texas A\&M University, College Station 77843
}

\begin{abstract}
Average diameters and particle size distributions in fluid milks with different fat contents and subjected to various homogenization pressures with a "microfluidizer" were evaluated. Skim, $2 \%$, and whole milks were microfluidized at 50,100,150, and $200 \mathrm{MPa}$. Cream containing $41 \%$ milk fat was microfluidized at 50, 100, and $150 \mathrm{MPa}$. Particle sizes were determined by laser light scattering. As microfluidization pressure was increased from 50 to $100 \mathrm{MPa}$, particle sizes in skim, $2 \%$, and whole milks decreased. Microfluidization at pressures greater than $100 \mathrm{MPa}$ had little additional effect on reducing the particle sizes in skim and $2 \%$ milks compared with microfluidization at $100 \mathrm{MPa}$, but the particle sizes in whole milk increased as the microfluidization pressure was increased from 100 to 200 $\mathrm{MPa}$ due to formation of homogenization clusters. The particle sizes in cream increased as the microfluidization pressure was increased from 50 to $150 \mathrm{MPa}$. When the microfluidization pressure was held constant, the particle sizes increased as the milk fat concentration was increased. The coefficients of variations of the volume-weighted particle size distributions for cream were higher than for skim, $2 \%$, and whole milks. Larger "big" particles and smaller "small" particles were formed in whole milk after microfluidization at $200 \mathrm{MPa}$ than at $100 \mathrm{MPa}$. Although microfluidization can be used to produce small particles in skim, $2 \%$, and whole milks, a higher than optimum pressure (above $100 \mathrm{MPa}$ ) applied to whole milk will not lead to the minimum $\mathrm{d}_{43}$
\end{abstract}

Received February 4, 2003.

Accepted April 26, 2004.

Corresponding author: D. W. Olson; e-mail: dolson@errc.ars. usda.gov.

$\dagger$ Current address: Eastern Regional Research Center, ARS, USDA, 600 East Mermaid Lane, Wyndmoor, PA 19038

*Approved for publication as Journal Article No. J-10286 of the Mississippi Agricultural and Forestry Experiment Station, Mississippi State University. Research funded in part by the Mississippi Agricultural and Forestry Experiment Station Project No. MIS501020 and by Dairy Management, Inc. (volume-weighted average diameter) due to formation of clusters.

(Key words: particle sizing, microfluidization, homogenization, milk)

Abbreviation key: $\mathbf{d}_{43}=$ volume-weighted average diameter, $\mathbf{d}_{\mathbf{3 2}}=$ volume-surface average diameter, $\mathbf{C V}=$ coefficient of variation.

\section{INTRODUCTION}

Microfluidizers operate by a different mechanism and at different pressures than conventional valve homogenizers. Microfluidizers contain a double-acting intensifier pump and an interaction chamber (Anonymous, 2003). The intensifier pump may be air-driven or electric-hydraulic driven and provides high pressure to force the product through the interaction chamber. The interaction chamber contains fixed-geometry microchannels. Product divides into streams as it enters the interaction chamber and accelerates to a very high velocity as it flows through the interaction chamber. These streams collide with each other. Shear and impact occur to form emulsions with very small particles. A cooling coil after the interaction chamber may or may not be present. Homogenization with a microfluidizer (microfluidization) is usually performed at higher pressures than conventional valve homogenization. Some models of a microfluidizer can generate pressures up to $276 \mathrm{MPa}$. Therefore, like conventional valve homogenization, microfluidization leads to significant changes to the fat and protein in milk.

Microfluidization and conventional valve homogenization alter the milk fat globule membrane as well as disrupt fat globules. Henstra and Schmidt (1970) used transmission electron microscopy to show that casein particles break down and adsorb to fat globule surfaces in conventionally valve homogenized milk. Michalski et al. (2002) also showed that conventional valve homogenization formed fat-protein complexes with a new membrane. Dalgleish et al. (1996) reported that fewer intact or semi-intact micelles formed the membrane surrounding fat globules in microfluidized milk than in 
conventionally valve homogenized milk. Also, Dalgleish et al. (1996) observed new types of particles by transmission electron microscopy characterized by small fat globules embedded in casein micelles. These changes alter particle sizes.

Particle size is important for many properties of milk and dairy products. Beneficial examples of decreased particle size include decreased creaming rate (Walstra et al., 1999), less susceptibility to cold agglutination (Walstra et al., 1999), potential increased accuracy of fat content determination by calibration of infrared analyzers with microfluidized milk samples and microfluidization of milk prior to milk analysis (Remillard et al., 1993), increased heat stability of concentrated milk (Whiteley and Muir, 1996), production of protein-based fat replacers (Paquin et al., 1993), and improved whiteness of Cheddar cheese (Lemay et al., 1994). Fat globule size also affects the tendency for milk fat cluster formation (Walstra et al., 1999). Particle sizes in milk and cream are altered by conventional valve homogenization and microfluidization, and the mechanism and thermodynamics of fat globule disruption have been discussed by Walstra (1983) and Walstra et al. (1999).

Although particle sizes have been commonly measured in whole milk subjected to microfluidization pressures not exceeding $103 \mathrm{MPa}$ (Pouliot et al., 1991; McCrae, 1994; Strawbridge et al., 1995; Dalgleish et al., 1996; Hardham et al., 2000), data on particle sizes in milks with varying fat contents or subjected to higher microfluidization pressure are limited. The objective of this study was to use laser light scattering to compare average sizes and particle size distributions in milks with various fat contents and in cream subjected to a wide range of microfluidization pressures up to 200 MPa.

\section{MATERIALS AND METHODS}

\section{Sample Preparation}

Pasteurized unhomogenized whole milk, pasteurized unhomogenized skim milk containing $0.14 \%$ fat, and raw cream containing $41 \%$ fat were obtained from the Mississippi State University dairy plant. Milks with 3.5 and $2.0 \%$ milk fat were prepared by mixing whole milk and skim milk. Whole milk containing $3.5 \%$ fat, $2 \%$ milk, and skim milk were heated from 4 to $39^{\circ} \mathrm{C}$ before one-pass homogenization in a Microfluidics M210-EH "Microfluidizer" (Microfluidics International Corporation, Newton, MA) at 50, 100, 150, or $200 \mathrm{MPa}$ for each of 3 replicates. Cream was heated from 4 to $39^{\circ} \mathrm{C}$ and subjected to one-pass microfluidization at 50, 100 , or $150 \mathrm{MPa}$ in one replicate. Additional replicates were not performed due to difficulty in microfluidizing $41 \%$ fat cream because of the high viscosities that devel- oped, especially at the higher pressures. The samples were cooled and transported on ice in coolers to Texas A\&M University for particle size analysis.

\section{Fat Content Determination}

The Mojonnier method according to the Mojonnier Instruction Manual (Anonymous, 1922) was used to determine fat content of the milks and cream. This method is based on extracting fat from a weighed amount of milk (or other types of dairy products) with ethyl ether and petroleum ether in specially designed flasks, decanting this ether phase into a preweighed weighing dish, evaporating the ether phase, and reweighing the weighing dish containing the extracted fat.

\section{Particle Size Determination}

Average particle sizes $\left(\mathrm{d}_{43}\right.$ and $\mathrm{d}_{32}$ [arithmetic means]) and size distributions (coefficient of variations, standard deviations, and particle sizes that define the upper size limit for $10,25,50,75$, and $90 \%$ of colloidal material in the volume-weighted size distributions) were determined using a Coulter LS 130 Small Volume Module particle size analyzer (Coulter Corporation, Miami, FL). This instrument measures particle sizes by analyzing the diffraction of laser light and the polarization intensity differential scattering (Anonymous, 1994). Samples were heated to approximately $37^{\circ} \mathrm{C}$ in a water bath before analysis. A sufficient amount of milk or cream was added to distilled water in the sample cell of the particle size analyzer until a polarization intensity differential scattering obscuration of 40 to $60 \%$ was obtained (Anonymous, 1994). An optical model based on Mie theory of light scattering by spherical particles was made using values for the real refractive index of 1.503 for skim milk, 1.471 for $2 \%$ milk and whole milk, and 1.460 for cream, and a value of 0 for skim milk, $2 \%$ milk, whole milk, and cream for the imaginary refractive index. The refractive index used for skim milk and cream was based on the refractive index of 1.503 measured for bovine casein micelles (Attaie and Richter, 2000) and 1.46 reported for milk fat globules (Michalski et al., 2001), respectively. Unless specified otherwise, average particle sizes in this manuscript refer to $d_{43}$ instead of $d_{32}$.

\section{Statistical Analysis}

The $\mathrm{d}_{43}$ and CV of the volume-weighted particle size distribution in microfluidized skim milk, $2 \%$ milk, and whole milk were analyzed with SAS System for Windows version 8 (SAS/STAT User's Guide, 1999) using 
Table 1. The $\mathrm{d}_{43}$ of particles in unhomogenized and microfluidized $(50,100,150$, and $200 \mathrm{MPa})$ fluid milks with various fat contents versus the corresponding $d_{32}$. The $d_{32}$ are in parentheses. All diameters are in $\mathrm{nm}$.

\begin{tabular}{llllc}
\hline & \multicolumn{4}{c}{ Type of fluid milk } \\
\cline { 2 - 5 } $\begin{array}{l}\text { Pressure } \\
\text { MPa })\end{array}$ & Skim & $2 \%$ & Whole & $\begin{array}{l}41 \% \\
\text { Cream }\end{array}$ \\
\hline 0 & 383.7 & 3652 & 4489 & 11090 \\
& $(212.3)$ & $(2719)$ & $(3278)$ & $(3721)$ \\
50 & $230.3^{\mathrm{c}, \mathrm{x}}$ & $392.7^{\mathrm{b}, \mathrm{x}}$ & $460.0^{\mathrm{a}, \mathrm{x}}$ & 5375 \\
& $(191.3)$ & $(262.7)$ & $(300.7)$ & $(1784)$ \\
100 & $208.0^{\mathrm{c}, \mathrm{y}}$ & $275.3^{\mathrm{b}, \mathrm{y}}$ & $304.3^{\mathrm{a}, \mathrm{z}}$ & 11920 \\
& $(178.0)$ & $(219.7)$ & $(239.0)$ & $(1977)$ \\
150 & $204.7^{\mathrm{c}, \mathrm{y}}$ & $270.0^{\mathrm{b}, \mathrm{y}}$ & $361.0^{\mathrm{a}, \mathrm{y}}$ & 26440 \\
& $(176.0)$ & $(215.3)$ & $(238.3)$ & $(2521)$ \\
200 & $205.7^{\mathrm{c}, \mathrm{y}}$ & $268.0^{\mathrm{b}, \mathrm{y}}$ & $383.3^{\mathrm{a}, \mathrm{y}}$ & \\
& $(177.3)$ & $(213.3)$ & $(236.7)$ & \\
\hline
\end{tabular}

a,b,c Means of $d_{43}$ not containing a common letter $(a, b$, or $c)$ in a given row (different type of fluid milk subjected to a given microfluidization pressure $)$ are significantly $(P<0.05)$ different from each other by the Bonferroni $t$-test.

$\mathrm{x}, \mathrm{y}, \mathrm{z}$ Means of $\mathrm{d}_{43}$ not containing a common letter ( $\mathrm{x}, \mathrm{y}$, or $\mathrm{z}$ ) in a given column (the same type of fluid milk subjected to different microfluidization pressures) are significantly $(P<0.05)$ different from each other by the Bonferroni $t$-test.

the general linear models procedure. The effect of each microfluidization pressure on the $\mathrm{d}_{43}$ and CV for milks with a given fat content and the effect of each fat content on the $\mathrm{d}_{43}$ and CV for milks subjected to a given microfluidization pressure were analyzed as separate randomized complete block designs. Mean separations at $P=0.05$ were performed by the Bonferroni $t$-test, and $P$ values for differences between each pair of treatments were determined according to the $t$-test. The unhomogenized samples were not included in the statistical analyses because of the high variance among different replicates of the unhomogenized samples compared with the microfluidized samples.

\section{RESULTS AND DISCUSSION}

\section{Mean Particle Sizes}

The effects of fat content and microfluidization pressure on the $\mathrm{d}_{43}$ and the corresponding $\mathrm{d}_{32}$ of particles can be determined from Table 1. Microfluidization pressure significantly $(P<0.001)$ affected particle sizes in skim milk, $2 \%$ milk, and whole milk. The $\mathrm{d}_{43}$ of particles in unhomogenized whole milk and $2 \%$ milk was reduced almost 10 -fold after microfluidization at $50 \mathrm{MPa}$, but this reduction of $\mathrm{d}_{43}$ for skim milk was less than 2 -fold. For skim milk, $2 \%$ milk, and whole milk, the $\mathrm{d}_{43}$ of particles significantly $(P<0.001)$ decreased as the microfluidization pressure was increased from 50 to 100
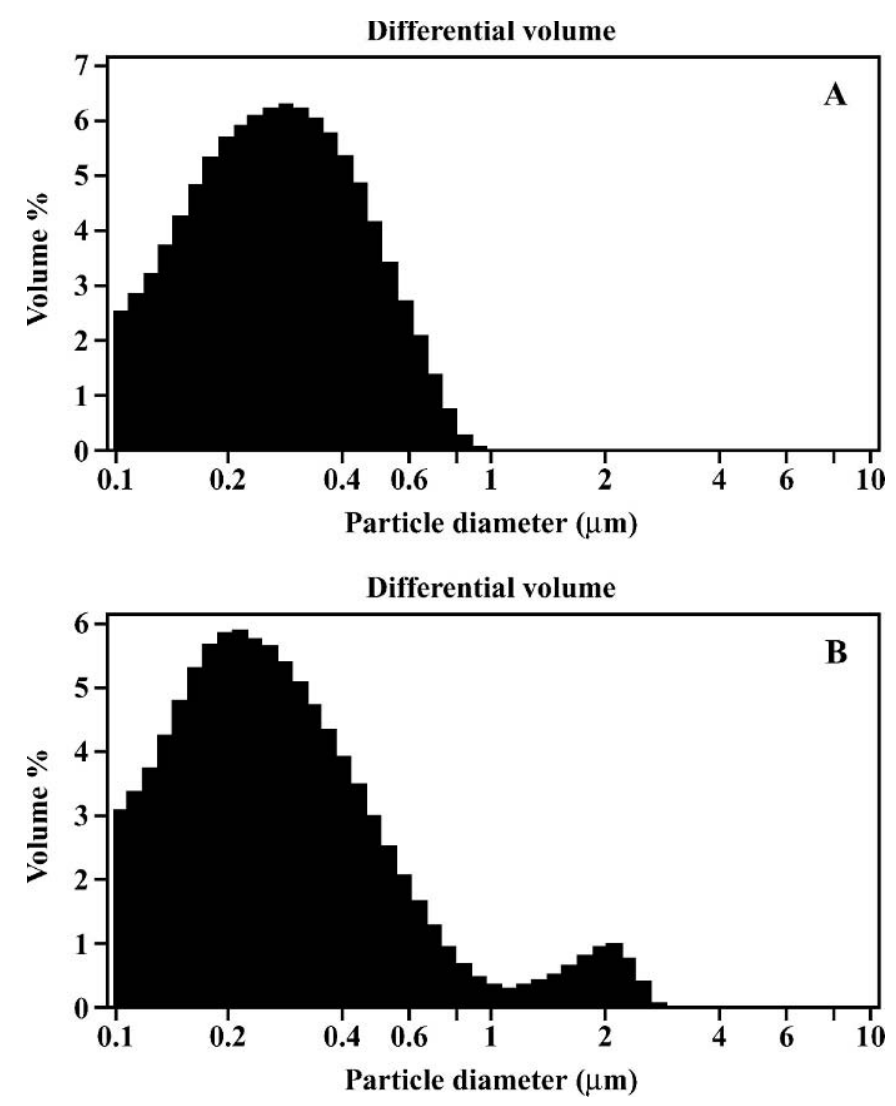

Figure 1. Particle size distribution in whole milk microfluidized at a) $100 \mathrm{MPa}$ and b) $200 \mathrm{MPa}$.

$\mathrm{MPa}$. Additional increases in microfluidization pressure did not cause further reductions in the $\mathrm{d}_{43}$ of particles in skim milk and $2 \%$ milk compared with microfluidization at $100 \mathrm{MPa}(P>0.05)$. However, the $\mathrm{d}_{43}$ of particles in whole milk significantly $(P<0.001)$ increased from 304 to $383 \mathrm{~nm}$ as the microfluidization pressure was increased from 100 to $200 \mathrm{MPa}$. The particle size distributions in whole milk microfluidized at 100 and $200 \mathrm{MPa}$ are shown in Figure 1. Particles less than $100 \mathrm{~nm}$ could not be detected by the particle size analyzer, but these particles are thought to only have a minor effect on the $d_{43}$ and $d_{32}$. Although the $d_{43}$ of particles in cream containing $41 \%$ milk fat decreased by approximately one-half during microfluidization at $50 \mathrm{MPa}$, the $\mathrm{d}_{43}$ increased when the microfluidization pressure was increased from 50 to $150 \mathrm{MPa}$. The fat content had a significant $(P<0.001)$ effect on particle size at each microfluidization pressure. When holding microfluidization pressure constant, the $\mathrm{d}_{43}$ of particles in whole milk was significantly $(P<0.005)$ greater than $\mathrm{d}_{43}$ of particles in $2 \%$ milk, and $\mathrm{d}_{43}$ of particles in $2 \%$ milk was significantly $(P<0.005)$ greater than $\mathrm{d}_{43}$ of particles in skim milk. The $d_{43}$ of particles in the $41 \%$ 
Table 2. The average CV (in \%) for volume-weighted particle size distributions for unhomogenized and microfluidized (50, 100, 150, and $200 \mathrm{MPa}$ ) skim milk, $2 \%$ milk, whole milk, and $41 \%$ cream.

\begin{tabular}{lllll}
\hline & \multicolumn{4}{c}{ Type of fluid milk } \\
\cline { 2 - 5 } $\begin{array}{l}\text { Pressure } \\
\text { (MPa) }\end{array}$ & Skim & $2 \%$ & Whole & $\begin{array}{l}41 \% \\
\text { Cream }\end{array}$ \\
\hline 0 & 113 & 41.9 & 101 & 209 \\
50 & $48.1^{\mathrm{b}, \mathrm{x}}$ & $86.4^{\mathrm{a}, \mathrm{x}}$ & $83.6^{\mathrm{a}, \mathrm{y}}$ & 212 \\
100 & $44.1^{\mathrm{b}, \mathrm{y}}$ & $50.0^{\mathrm{a}, \mathrm{y}}$ & $50.0^{\mathrm{a}, \mathrm{z}}$ & 254 \\
150 & $43.3^{\mathrm{c}, \mathrm{yz}}$ & $50.6^{\mathrm{b}, \mathrm{y}}$ & $100^{\mathrm{a}, \mathrm{xy}}$ & 148 \\
200 & $42.6^{\mathrm{b}, \mathrm{z}}$ & $51.6^{\mathrm{b}, \mathrm{y}}$ & $112^{\mathrm{a}, \mathrm{x}}$ & \\
\hline
\end{tabular}

a,b,c Means of CV not containing a common letter $(a, b$, or $c)$ in a given row (different type of fluid milk subjected to a given microfluidization pressure $)$ are significantly $(P<0.05)$ different from each other by the Bonferroni $t$-test.

${ }^{x, y, z}$ Means of CV not containing a common letter ( $x, y$, or $\left.z\right)$ in a given column (the same type of fluid milk subjected to different microfluidization pressures) are significantly $(P<0.05)$ different from each other by the Bonferroni $t$-test.

cream samples were approximately 3 to 10 times higher than the corresponding $d_{32}$. The particle size distribution for each of these cream samples contained multiple peaks as indicated by the large $\mathrm{CV}$ of the particle sizes for these samples (Table 2).

Although no attempt was made to identify types of particles in the samples during the particle size analysis in this study, casein micelles and fat globules constitute nearly all of the particles that have sizes in the range that can be detected by the particle size analyzer used in this study. Casein micelles typically have diameters between 30 and $300 \mathrm{~nm}$ (Swaisgood, 1996), so the larger micelles could have been detected by the particle size analyzer and should have had an influence on the particle size distributions of all of the unhomogenized samples. These effects of casein micelles on the particle size distributions of the unhomogenized samples should be more apparent in skim milk than in products that contain milk fat because the fat globules may overshadow the casein micelles in the products that contain fat. Because relatively few fat globules are present in skim milk, the larger particles in $2 \%$ and whole milks and $41 \%$ fat cream compared to skim milk were due to more and larger fat globules in products containing fat. Since almost all of the larger particles detected in unhomogenized skim milk were smaller than the majority of particles detected in unhomogenized $2 \%$ and whole milks and cream, these few fat globules in skim milk not effectively removed by separation were predominantly small fat globules.

The fat globule sizes in unhomogenized whole milk measured in other studies were often similar to the particle sizes measured in the present study. The $\mathrm{d}_{32}$ for fat globules in cows' milk were $3.34 \mu \mathrm{m}$ when measured using a Coulter counter, fluorescence microscopy, or spectroturbidimetry (Walstra, 1969), $3.5 \mu \mathrm{m}$ when measured by spectroturbidimetry (Walstra, 1975), and 3.51 $\mu \mathrm{m}$ when measured by laser light scattering (Attaie and Richter, 2000) compared with a $\mathrm{d}_{32}$ of $3.278 \mu \mathrm{m}$ obtained in the present study. Remillard et al. (1993) used photon correlation spectroscopy and reported a $\mathrm{d}_{43}$ of $3.04 \mu \mathrm{m}$ for fat globules in raw cows' milk after treatment with a protein dissociating buffer compared with a $\mathrm{d}_{43}$ of $4.489 \mu \mathrm{m}$ without the use of a protein dissociating buffer in the present study

Microfluidization produced smaller particles in milk at $35 \mathrm{MPa}$ (McCrae, 1994) and in concentrated milk at $34 \mathrm{MPa}$ (Whiteley and Muir, 1996) than conventional valve homogenization at the equivalent pressure. Microfluidization can usually be performed at higher pressures than conventional valve homogenization, often leading to even smaller particles. However, McCrae (1994) reported that the extrapolated rate at which the average fat globule size decreased with increasing pressure was greater for conventional valve homogenization than for microfluidization. McCrae (1994) predicted by extrapolation that an equivalent average size of fat globules in milk would be obtained after microfluidization at $103 \mathrm{MPa}$ compared with conventional valve homogenization at $63 \mathrm{MPa}$.

Decreased average particle sizes in whole milk were found when increasing the microfluidization pressure from 14 to $42 \mathrm{MPa}$ (Dalgleish et al., 1996), from 19.3 to $67.6 \mathrm{MPa}$ (Pouliot et al., 1991), and from 35 to 103 $\mathrm{MPa}$ (McCrae, 1994). These trends for effect of microfluidization pressure up to $103 \mathrm{MPa}$ on average particle sizes agree with the trend of decreasing average particle size when increasing microfluidization pressure from 50 to $100 \mathrm{MPa}$ in the present study. However, microfluidization at $100 \mathrm{MPa}$ produced the smallest average size particle in whole milk, and average particle sizes increased when microfluidization pressure was increased above $100 \mathrm{MPa}$.

Lemay et al. (1994) found that average sizes of fat globules in $15 \%$ fat cream decreased as microfluidization pressure was increased from 14 to $69 \mathrm{MPa}$. This trend of decreased particle size with increasing microfluidization pressure did not agree with the results from the present study. Possible explanations for the different trends include a different range of microfluidization pressures (14 to $69 \mathrm{MPa}$ vs. 50 to $150 \mathrm{MPa}$ ) and different fat contents of the creams (15 vs. $41 \%$ ).

Some of the decreases in particle sizes that occurred in skim milk, $2 \%$ milk, and whole milk in the present study were probably due to the increased microfluidization temperature that accompanied the increased microfluidization pressure. Tunick et al. (2000, 2002) found large decreases in fat globule sizes in Mozzarella 
cheese after the microfluidization temperature of the cheesemilk was increased from 10 to $54^{\circ} \mathrm{C}$.

\section{CV and Standard Deviations}

The average $\mathrm{CV}$ for the volume-weighted particle size distributions are presented in Table 2 . The average CV for unhomogenized skim milk was more than twice as high as the average CV for microfluidized skim milk. Skim milk and $2 \%$ milk microfluidized at $50 \mathrm{MPa}$ had significantly $(P<0.001)$ higher $\mathrm{CV}$ than skim milk and $2 \%$ milk, respectively, microfluidized at 100,150 , and $200 \mathrm{MPa}$. For whole milk, microfluidization at $200 \mathrm{MPa}$ resulted in a significantly $(P<0.01)$ higher $\mathrm{CV}$ than microfluidization at 50 and $100 \mathrm{MPa}$, and microfluidization at $100 \mathrm{MPa}$ resulted in significantly $(P<0.001)$ lower $\mathrm{CV}$ than the remaining microfluidization pressures. When holding microfluidization pressure constant, whole milk had significantly $(P=0.001)$ higher CV than skim milk at all microfluidization pressures, and $2 \%$ milk had significantly $(P<0.05)$ larger CV than skim milk after microfluidization at 50, 100, and 150 $\mathrm{MPa}$. Except for cream microfluidized at $150 \mathrm{MPa}$, the CV of the cream samples were over $200 \%$. These high $\mathrm{CV}$ for cream were caused by multiple peaks in their particle size distribution.

The width of particle size distribution from another study was compared to the width of particle size distributions in the present study. The standard deviation of $110 \mathrm{~nm}$ for the volume-weighted size distribution of fat globules in whole milk microfluidized at $69 \mathrm{MPa}$ in the study of Remillard et al. (1993) was less than the standard deviations of 369 to $411 \mathrm{~nm}$ and 151 to $153 \mathrm{~nm}$ for the volume-weighted size distribution of all particles after microfluidization of whole milk at 50 and $100 \mathrm{MPa}$, respectively, in the present study (data not shown). Part of this difference in standard deviation may be due to use of a dissociating buffer in the study of Remillard et al. (1993).

\section{Cumulative Distribution of Particle Size}

The particle sizes that defined the upper size limit for $10,25,50,75$, and $90 \%$ of the colloidal material are presented in Table 3. This partitioning showed that microfluidization affected the particle size distributions in several ways. First, unhomogenized skim milk had $90 \%$ of its colloidal material in particles with diameters less than $1015 \mathrm{~nm}$, but after microfluidization at 200 $\mathrm{MPa}, 90 \%$ of the colloidal material was in particles that had a diameter less than $331 \mathrm{~nm}$. The respective values for $10 \%$ of the colloidal material were $121 \mathrm{~nm}$ for unhomogenized skim milk and $116 \mathrm{~nm}$ for skim milk microfluidized at $200 \mathrm{MPa}$. Therefore, the decreased parti- cle sizes in skim milk after being microfluidized were primarily due to reducing the size of larger particles such as fat globules rather than of smaller particles such as casein micelles. Second, particles that were the sizes of casein micelles were generally not observed in unhomogenized $2 \%$ and whole milks. This observation might be explained by the large fat globules preventing the observation of the smaller particles by the particle size analyzer. After microfluidization of $2 \%$ and whole milks, particles less than $160 \mathrm{~nm}$ were observed as shown by the particle sizes for $10 \%$ of the colloidal material for the $2 \%$ and whole milks. These small particles with sizes typically reported for casein micelles were likely homogenization clusters of protein and milk fat as will be discussed in the next section. Finally, the particle sizes in whole milk which defined 10,25 , and $50 \%$ of the colloidal material decreased as microfluidization pressure was increased from 100 to $200 \mathrm{MPa}$, but the particle sizes in whole milk that defined 75 and $90 \%$ of the colloidal material increased as microfluidization pressure was increased from 100 to $200 \mathrm{MPa}$. Therefore, there were larger "large" particles and smaller "small" particles in whole milk microfluidized at $200 \mathrm{MPa}$ than in whole milk microfluidized at 100 MPa. This interpretation was supported by the $d_{43}$ and CV because there was a $26 \%$ increase in $\mathrm{d}_{43}$ (Table 1 ) and more than a 2-fold increase in CV (Table 2) for whole milk microfluidized at $200 \mathrm{MPa}$ compared with $100 \mathrm{MPa}$.

A similarity existed between the changes of variously sized particles in the present study and the study of Strawbridge et al. (1995). Smaller reductions in sizes of smaller particles than for larger particles after microfluidization of whole milk were found when microfluidization pressure was increased from 50 to 100 $\mathrm{MPa}$ in the present study and from 14 to $42 \mathrm{MPa}$ in the study of Strawbridge et al. (1995).

The rate of instability, including creaming, is reduced by reducing the size of the larger particles (Robin et al., 1992). Microfluidization of whole milk at $100 \mathrm{MPa}$ would probably prolong the shelf life in terms of delaying creaming more than the other treatments for whole milk in the present study since the particle size below which $90 \%$ of the volume of the colloidal material lie was lower for this treatment than for the other treatments. This potential to delay creaming may be beneficial for milks with a long shelf life such as sterilized milk and concentrated milk. Microfluidization at 70 $\mathrm{MPa}$ instead of conventional valve homogenization at 17.5 $\mathrm{MPa}$ first stage and 3.5 $\mathrm{MPa}$ second stage increased shelf life of ultra-high temperature processed milk in terms of fat separation in the study of Hardham et al. (2000). 
Table 3. The diameter (in $\mathrm{nm}$ ) of particles in which the given percentage of colloidal material was in smaller particles for the volume-weighted particle size distribution for unhomogenized and microfluidized (50, 100, 150 , and $200 \mathrm{MPa}$ ) skim milk, $2 \%$ milk, whole milk, and $41 \%$ cream.

\begin{tabular}{|c|c|c|c|c|c|c|}
\hline \multirow{2}{*}{$\begin{array}{l}\text { Pressure } \\
(\mathrm{MPa})\end{array}$} & \multirow{2}{*}{$\begin{array}{l}\text { Type of } \\
\text { fluid milk }\end{array}$} & \multicolumn{5}{|c|}{ Percentage of colloidal material } \\
\hline & & 10 & 25 & 50 & 75 & 90 \\
\hline \multirow[t]{4}{*}{0} & Skim & 121 & 153 & 214 & 358 & 1015 \\
\hline & $2 \%$ & 1943 & 2538 & 3414 & 4552 & 5796 \\
\hline & Whole & 2180 & 2713 & 3472 & 4410 & 5470 \\
\hline & Cream & 2001 & 2746 & 4070 & 6652 & 20230 \\
\hline \multirow{4}{*}{50} & Skim & 119 & 149 & 201 & 281 & 385 \\
\hline & $2 \%$ & 141 & 196 & 305 & 466 & 672 \\
\hline & Whole & 158 & 231 & 357 & 535 & 802 \\
\hline & Cream & 849 & 1341 & 2395 & 4152 & 6760 \\
\hline \multirow[t]{4}{*}{100} & Skim & 116 & 140 & 183 & 249 & 339 \\
\hline & $2 \%$ & 129 & 169 & 241 & 350 & 474 \\
\hline & Whole & 136 & 184 & 270 & 392 & 524 \\
\hline & Cream & 929 & 1471 & 2578 & 4894 & 17450 \\
\hline \multirow[t]{4}{*}{150} & Skim & 115 & 139 & 182 & 245 & 331 \\
\hline & $2 \%$ & 127 & 166 & 235 & 341 & 466 \\
\hline & Whole & 133 & 179 & 263 & 402 & 594 \\
\hline & Cream & 1029 & 1727 & 3625 & 48220 & 95830 \\
\hline \multirow[t]{3}{*}{200} & Skim & 116 & 140 & 183 & 247 & 331 \\
\hline & $2 \%$ & 126 & 164 & 231 & 337 & 466 \\
\hline & Whole & 132 & 175 & 259 & 404 & 637 \\
\hline
\end{tabular}

\section{Homogenization Clustering}

The increase in the size of the largest particles in whole milk with increasing microfluidization pressure was probably due to formation of new particles of fat and protein. Although structures resembling homogenization clusters of 2 fat globules with shared proteinaceous material in whole milk microfluidized at 100 and $200 \mathrm{MPa}$ were observed in transmission electron micrographs for other samples (Olson, 2000), clustering in the form of extensive complexes (especially fat and protein connected in the form of chains and aggregates) and proteinaceous material containing embedded fat globules were much more prevalent. Walstra (1980) reported that the larger casein micelles were disrupted at high pressures and reassociated after conventional valve homogenization.

Cream samples were not observed under a transmission electron microscope, so the microstructure of this sample is unknown. The large particles in cream were most likely large homogenization clusters of fat and protein in the form of chains and aggregates. Although the high cream viscosity that developed during microfluidization, especially at the higher pressures, indicated that extensive homogenization clustering and possibly some coalecence occurred during microfluidization, the possibility that some partial coalescence could have occurred after microfluidization but before particle size analysis leading to an increased average particle size can not be ruled out.

The extent of homogenization clustering is affected by homogenization pressure, fat content, homogenization temperature, and fat globule size. Clustering becomes more prevalent with increased amount of newly created surface area relative to the amount of shareable surfactant (Ogden et al., 1976), explaining the increased clustering with increased homogenization pressure or a higher fat content (Doan, 1929). Extent of clustering as judged by the particle size distributions in the present study increased as microfluidization pressure and fat content increased. However, the extent of clustering decreased with increasing microfluidization pressure in the study of McCrae (1994). McCrae (1994) suggested that the lower than expected amount of clustering in microfluidized milk, especially at higher pressures, was due to a high protein load in microfluidized milk. Although clustering was observed in whole milk in the present study, Walstra (1983) stated that clustering does not usually occur when the fat content of fluid milk is less than 9\%. This statement by Walstra (1983) probably only applies to conventional valve homogenization performed at pressures lower than the microfluidization pressures used in the present study. Also, clustering is favored by low conventional valve homogenization temperatures (Mulder and Walstra, 1974). The Deryaguin-Landau and Verwey-Overbeek (DLVO) theory predicts that the fat globule diameter influences the tendency of cluster formation (Kurzhals, 1973).

\section{CONCLUSIONS}

The effect of microfluidization pressures between 50 and $200 \mathrm{MPa}$ on average particle sizes and the volumeweighted particle size distributions of skim milk, $2 \%$ 
milk, whole milk, and $41 \%$ cream was evaluated in this study. The $\mathrm{d}_{43}$ of particles in skim, $2 \%$, and whole milks decreased when microfluidization pressure was increased from 50 to $100 \mathrm{MPa}$. Although additional increases in microfluidization pressure above $100 \mathrm{MPa}$ did not significantly change the $\mathrm{d}_{43}$ of particles in skim and $2 \%$ milks compared to microfluidization at 100 $\mathrm{MPa}$, the $\mathrm{d}_{43}$ of particles in whole milk increased from 304 to $383 \mathrm{~nm}$ when the microfluidization pressure was increased from 100 to $200 \mathrm{MPa}$. The $\mathrm{d}_{43}$ of particles in microfluidized cream increased as the microfluidization pressure was increased from 50 to $150 \mathrm{MPa}$. This increased particle size was probably due to formation of homogenization clusters in the form of chains and aggregates of fat and protein in whole milk and cream and possibly also from some coalescence of fat globules in the cream. Microfluidization led to greater reductions of size of the larger particles compared with the smaller particles in skim milk. However, the cumulative particle size distribution in whole milk showed that there were larger "large" particles and smaller "small" particles after microfluidization at 150 and $200 \mathrm{MPa}$ than at $100 \mathrm{MPa}$. Smaller "large" particles produced by microfluidization of whole milk at $100 \mathrm{MPa}$ instead of 50,150 , or $200 \mathrm{MPa}$ should prolong the time before creaming occurs, and this potential increased stability may be beneficial for products with a long shelf life such as in UHT processed whole milk or concentrated milk.

\section{ACKNOWLEDGMENTS}

The funding for this research project by Dairy Management, Inc., was gratefully acknowledged. The authors thank the staff in the laboratory of Ron Richter for their assistance with the use of the Coulter LS 130 Small Volume Module particle size analyzer.

\section{REFERENCES}

Anonymous. 1922. Mojonnier milk tester instruction manual. Bulletin No. 101. Mojonnier Bros. Co., Chicago, IL.

Anonymous. 1994. Coulter LS Series Product Manual. Coulter Corp., Miami, FL.

Anonymous. 2003. http://www.microfluidicscorp.com/ Microfluidics, Newton, MA.

Attaie, R., and R. L. Richter. 2000. Size distribution of fat globules in goat milk. J. Dairy Sci. 83:940-944.

Dalgleish, D. G., S. M. Tosh, and S. West. 1996. Beyond homogenization: The formation of very small emulsion droplets during the processing of milk by a Microfluidizer. Neth. Milk Dairy J. 50:135-148.

Doan, F. J. 1929. Some factors affecting the fat clumping produced in milk and cream mixtures when homogenized. J. Dairy Sci. 12:211-230.

Hardham, J. F., B. W. Imison, and H. M. French. 2000. Effect of homogenisation and microfluidisation on the extent of fat separation during storage of UHT milk. Aust. J. Dairy Technol. $55: 16-22$.
Henstra, S., and D. G. Schmidt. 1970. On the structure of the fatprotein complex in homogenized cow's milk. Neth. Milk Dairy J. $24: 45-51$.

Kurzhals, H. A. 1973. Evaluation of the effect of homogenization on milk. Milchwissenschaft 28:637-645.

Lemay, A., P. Paquin, and C. Lacroix. 1994. Influence of microfluidization of milk on Cheddar cheese composition, color, texture, and yield. J. Dairy Sci. 77:2870-2879.

McCrae, C. 1994. Homogenization of milk emulsions: Use of microfluidizer. J. Soc. Dairy Technol. 47:28-31.

Michalski, M. C., V. Briard, and F. Michel. 2001. Optical parameters of milk fat globules for laser light scattering measurements. Lait 81:787-796.

Michalski, M. C., F. Michel, and C. Geneste. 2002. Appearance of submicronic particles in the milk fat globule size distribution upon mechanical treatments. Lait 82:193-208.

Mulder, H., and P. Walstra. 1974. The Milk Fat Globule. Emulsion Science as Applied to Milk Products and Comparable Foods. Commonwealth Agric. Bur. Farnham Royal, Bucks, England.

Ogden, L. V., P. Walstra, and H. A. Morris. 1976. Homogenizationinduced clustering of fat globules in cream and model systems. J. Dairy Sci. 59:1727-1737.

Olson, D. W. 2000. Properties of milk and frozen dairy desserts processed by microfluidization. Ph.D. dissertation, Mississippi State University, Mississippi State.

Paquin, P., Y. Lebeuf, J. P. Richard, and M. Kalab. 1993. Microparticulation of milk proteins by high pressure homogenization to produce a fat substitute. Int. Dairy Fed. Special Issue No. 9303:389-396. IDF, Brussels, Belgium.

Pouliot, Y., P. Paquin, O. Robin, and J. Giasson. 1991. Etude comparative de l'effet de la microfluidisation et de l'homogeneisation sur la distribution de la taille des globules de gras du lait de vache. Int. Dairy J. 1:39-49.

Remillard, N., O. Robin, R. Martel, and P. Paquin. 1993. Influence of homogenization efficiency on milk fat content determination by infrared analysis. Int. Dairy J. 3:197-208.

Robin, O., V. Blanchot, J. C. Vuillemard, and P. Paquin. 1992. Microfluidization of dairy model emulsions. I. Preparation of emulsions and influence of processing and formulation on the size distribution of milk fat globules. Lait 72:511-531.

SAS/STAT User's Guide, Version 8 Edition. 1999. SAS Inst., Inc., Cary, NC.

Strawbridge, K. B., E. Ray, F. R. Hallett, S. M. Tosh, and D. G. Dalgleish. 1995. Measurement of particle size distributions in milk homogenized by a Microfluidizer: Estimation of populations of particles with radii less than $100 \mathrm{~nm}$. J. Colloid Interface Sci. 171:392-398.

Swaisgood, H. E. 1996. Characteristics of milk. Page 841 in Food Chemistry. 3rd ed. O. R. Fennema, ed. Marcel Dekker, Inc., New York, NY.

Tunick, M. H., D. L. Van Hekken, P. H. Cooke, and E. L. Malin. 2002. Transmission electron microscopy of Mozzarella cheese made from microfluidized milk. J. Agric. Food Chem. 50:99-103.

Tunick, M. H., D. L. Van Hekken, P. H. Cooke, and E. L. Malin. 2000. Effect of high pressure microfluidization on microstructure of Mozzarella cheese. Lebensm.-Wiss. u.-Technol. 33:538-544.

Walstra, P. 1969. Studies on milk fat dispersion. II. The globule-size distribution of cow's milk. Neth. Milk Dairy J. 23:99-110.

Walstra, P. 1975. Effect of homogenization on the fat globule size distribution in milk. Neth. Milk Dairy J. 29:279-294.

Walstra, P. 1980. Effect of homogenization on milk plasma. Neth. Milk Dairy J. 34:181-190.

Walstra, P. 1983. Physical chemistry of fat globules. Page 119 in Developments in Dairy Chemistry. 2. Lipids. P. F. Fox, ed. Appl. Sci. Publ., London, UK.

Walstra, P., T. J. Geurts, A. Noomen, A. Jellema, and M. A. J. S. Van Boekel. 1999. Dairy Technology: Principles of Milk Properties and Processes. Marcel Dekker, Inc., New York, NY.

Whiteley, A. J., and D. D. Muir. 1996. Heat stability of homogenised concentrated milk: 1 . Comparison of Microfluidiser with a valve homogeniser. Milchwissenschaft 51:320-323. 